\section{Postharvest Drying of Leyland Cypress, Eastern Red Cedar, and Fraser Fir Christmas Trees}

\author{
L. Eric Hinesley ${ }^{1}$ and Layne K. Snelling ${ }^{2}$ \\ Department of Horticultural Science, North Carolina State University, Raleigh, \\ NC 27695-7609
}

\section{Additional index words. Abies fraseri, x Cupressocyparis leylandii, Juniperus virginiana}

Abstract. Postharvest drying of Leyland cypress [x Cupressocyparis leylandii (A.B. Jacks. \& Dallim.)] branches was intermediate between eastern red cedar (Juniperus virginiana L.) and Fraser fir [Abies fraseri (Pursh) Poir.] in two laboratory experiments. Leyland cypress rehydrated without adverse effect until xylem pressure potential reached $\mathbf{- 4 . 0}$ to $-5.0 \mathrm{MPa}$ (shoot moisture content $=60 \%$ to $65 \%$ ). For branches continuously maintained in water, Fraser fir and Leyland cypress kept equally well over 4 weeks of display, but Leyland cypress lasted longer than Fraser fir over 8 weeks. Postharvest keeping quality of Leyland cypress and Fraser fir was better than that of eastern red cedar.

Leyland cypress, a sterile hybrid between Alaska cedar [Chamaecyparis nootkatensis (D. Don) Spach.] and Monterey cypress (Cupressus macrocarpa Hartweg.), is a popular ornamental and in recent years also has been cultivated in the southern United States as a Christmas tree (Schoenike and Gaffney, 1989). To our knowledge, postharvest keeping quality of Leyland cypress has not been reported. The ability of a tree species to maintain its quality following cutting is an important factor determining its use as a Christmas tree. Our objective was to determine postharvest drying rates for Leyland cypress and compare them with two other Christmas tree species: eastern red cedar and Fraser fir.

\section{Materials and Methods}

Fraser fir and Leyland cypress (Expt. 1). On 6 Dec. 1993, 10 uniform branches were collected from each of six Fraser fir Christmas trees at the Mountain Research Station, Waynesville, N.C. Branches were taken from the center portion of the crown and were 0.6 to $0.8 \mathrm{~m}$ long. Trees were 2.5 to $3 \mathrm{~m}$ tall. Branches were stood in water; transported to Raleigh, N.C.; and kept overnight at 5C.

On 7 Dec., a similar set of branches was collected from six Leyland cypress Christmas trees in Raleigh. Branches were stood in water and transported to the laboratory within $2 \mathrm{~h}$.

The experiment was initiated during the afternoon of 7 Dec. $($ day $=0)$. One branch from each tree was continuously held in water; the remaining branches were removed from wa-

Received for publication $26 \mathrm{Jan}$. 1995. Accepted for publication 5 May 1995. This research was funded by the North Carolina Agricultural Research Service, Raleigh. The cost of publishing this paper was defrayed in part by the payment of page charges. Under postal regulations, this paper therefore must be hereby marked advertisement solely to indicate this fact.

${ }^{1}$ Professor.

${ }^{2}$ Research Technician. ter. At varying intervals, one branch from each tree was recut under water, and immediately stood with its base in water. This continued for 10 days with Leyland cypress and 13 days for Fraser fir.

Containers were 20-liter buckets maintained at least three-fourths full. Foliage was removed from the submerged portion of branches. Ambient conditions were $21 \pm 1 \mathrm{C}$ with relative humidity (RH) at $50 \% \pm 10 \%$. Standard fluorescent lights operated from 0800 to 1700 HR Monday to Friday.

Using a pressure bomb (PMS Instrument Co., Corvalis, Ore.), xylem pressure potential $(\Psi)$ was measured initially and often enough afterwards to establish the drying and rehydration curve for branches from each tree. Shoots 12 to $15 \mathrm{~cm}$ long were detached from branches and used for measurements. These shoots were weighed when detached and after 3 days of drying at $65 \mathrm{C}$. Percentage of shoot moisture content (MC) was calculated as [(fresh weight - dry weight)/dry weight] $\times 100$.

The experiment ended after 28 days. Control branches (continuously in water) were maintained an additional 4 weeks to observe long-term keeping quality.

Leyland cypress and eastern red cedar (Expt. 2). Branches from four Leyland cypress and four eastern red cedar Christmas trees were collected on 10 Jan. 1994. Collection and handling were similar to Expt. 1. Cypresses were the same trees used in Expt. 1. Red cedars of similar age were in adjacent rows. The experiment began on $10 \mathrm{Jan}$. and ended 4 weeks later. The maximum drying period was 8 days. Procedures, laboratory conditions, and measurements were the same as in Expt. 1.

\section{Results and Discussion}

Among the three species, Fraser fir dried the most slowly (Fig. 1). Pressure potential reached $-2.5 \mathrm{MPa}$ on the first day, followed by a more gradual increase to $-4.2 \mathrm{MPa}$ by day 10. Drying accelerated thereafter. Branches resupplied with water at $\Psi$ values were equal to or greater than $-4.0 \mathrm{MPa}$ rehydrated to preharvest values between -0.5 and $-1.0 \mathrm{MPa}$ (Fig. 2A).

MC of Fraser fir decreased from $113 \%$ to $60 \%$ over 13 days (Fig. 2B). Branches quickly rehydrated when twig MC was $\geq 70 \%$. Branches

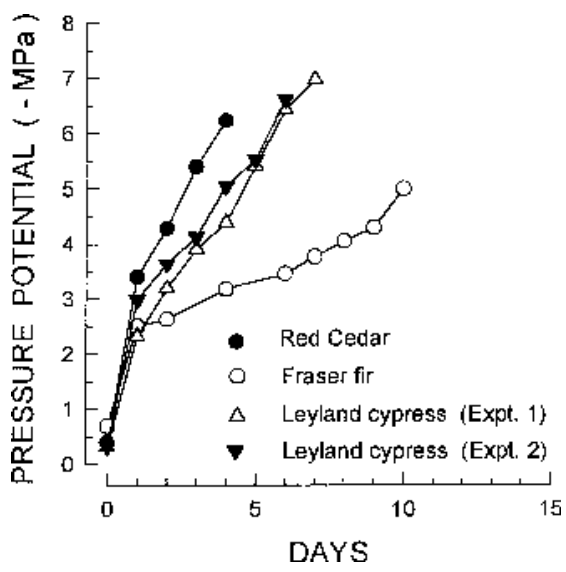

Fig. 1. Temporal change in xylem pressure potential $(\Psi)$ of $(\bullet)$ eastern red cedar, Leyland cypress [( $\Delta)$ Expt. 1, ( $\boldsymbol{\nabla})$ Expt. 2], and (O) Fraser fir maintained without water at $21 \mathrm{C}$ and $50 \% \pm$ $10 \%$ relative humidity. Values are means for six Fraser firs, four eastern red cedars, and six (Expt. 1) and four (Expt. 2) Leyland cypresses. Means for dry branches usually had SE $<5 \%$ of the mean.
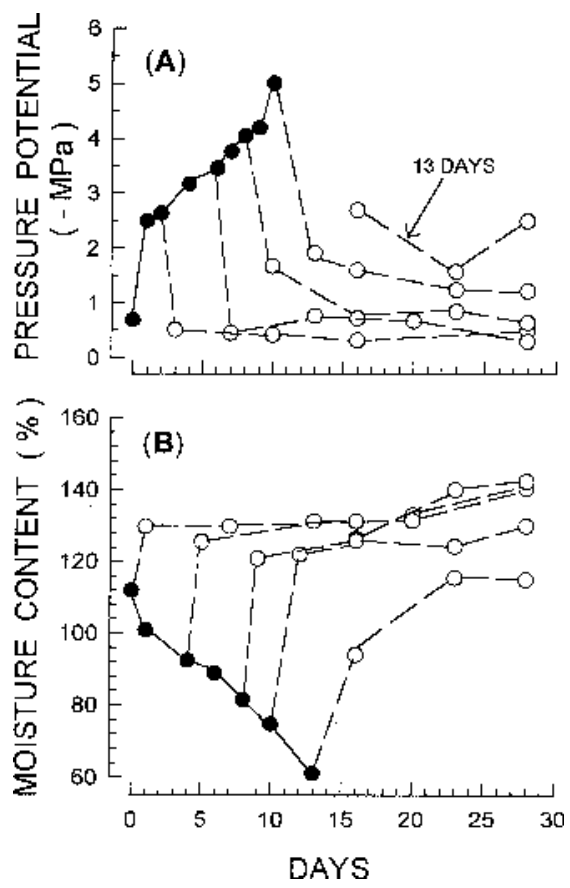

Fig. 2. (A) Xylem pressure potential and (B) moisture content of branches of Fraser fir after various drying times at $21 \mathrm{C}$ and $50 \% \pm 10 \%$ relative humidity (Expt. 1). (@) Branches out of water; (O) branches recut after designated periods of drying, and resupplied with water. Xylem pressure potential could not be determined on branches dried $>13$ days. Values shown are means for six trees. Means for dry branches usually had SE $<5 \%$ of the mean. Following rehydration, SES were rarely $20 \%$ of the mean, normally $<10 \%$. 
that were dried to $\approx 60 \% \mathrm{MC}$ rehydrated much more slowly, eventually reaching a MC close to the initial value, but the branches had deteriorated in quality by the 28th day. Branches resupplied with water soon after cutting normally reached a MC more than or equal to the preharvest levels.

Red cedar dried quickly, reaching -3.5 $\mathrm{MPa}$ in 1 day and -6.3 MPa in 4 days (Fig. 3). MC decreased from $130 \%$ to $30 \%$ after 7 days (Fig. 3B). The capacity to rehydrate was good if twig MC was $\geq 70 \%$. Branches returned to water soon after harvest reached $\mathrm{MC}$ above preharvest levels (Fig. 3B), as with Fraser fir (Fig. 2B). In contrast to the other species, red cedar branches began to lose moisture over time, beginning about the 10th day, even when returned to water soon after cutting (Fig. 3B).

Leyland cypress dried more slowly than eastern red cedar but more quickly than Fraser fir after harvest (Fig. 1). Leyland cypress reached $-2.3 \mathrm{MPa}$ the first day, and $\psi$ decreased linearly to $-7.0 \mathrm{MPa}$ by the 7 th day
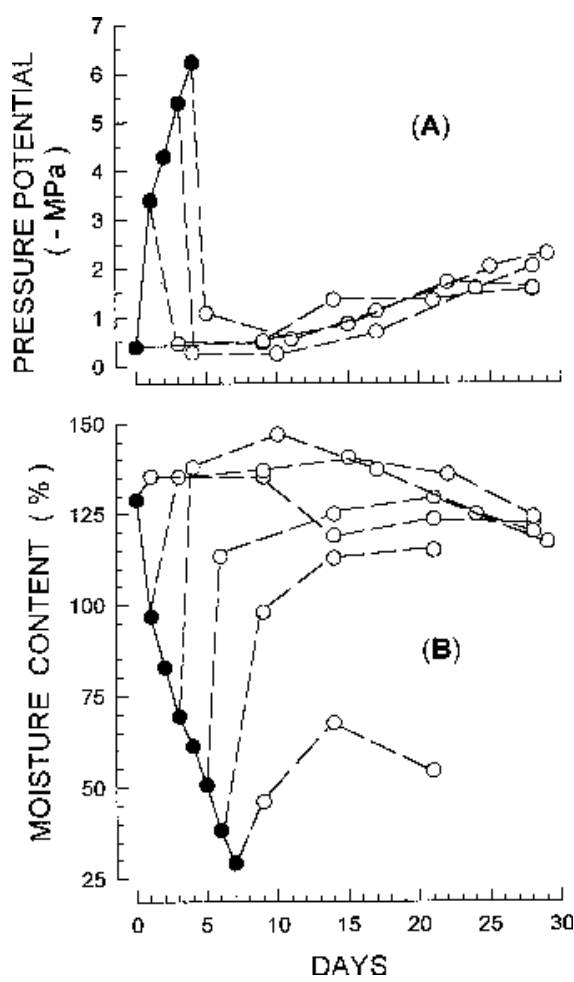

Fig. 3. (A) Xylem pressure potential and (B) moisture content of branches of eastern red cedar after various drying times at $21 \mathrm{C}$ and $50 \% \pm$ $10 \%$ relative humidity (Expt. 2). (-) Branches out of water; $(O)$ branches recut after designated periods of drying, and resupplied with water. Xylem pressure potential could not be determined on branches dried $>4$ days. Means for dry branches usually had SE $<5 \%$ of the mean. Following rehydration, sEs were rarely $20 \%$ of the mean, normally $<10 \%$.
(Fig. 4A). MC of Leyland cypress (Fig. 4B) decreased from $160 \%$ to $30 \%$ after 10 days. As with Fraser fir, branches placed in water soon after harvest reached MC more than or equal to initial levels (Fig. 4B) and tended to maintain a relatively constant $\Psi$ and MC. Branches quickly rehydrated to initial levels when shoot MC was $\geq 60 \%$. Branches dried to $\approx 40 \%$ MC took up a surprising amount of water, but the speed or extent of rehydration was reduced. These branches also deteriorated in quality before the end of the experiment.

Although Expt. 1 ended after 28 days, we observed the control branches (continuously supplied with water from day zero) for an additional month. After 8 weeks, Fraser fir had discolored and almost completely defoliated, mostly during the last 3 weeks, whereas Leyland cypress was still in relatively good condition (data not shown). Water remained clear in the buckets containing Leyland cypress; the water for Fraser fir became opaque. Chemical exudates from Leyland cypress ap-
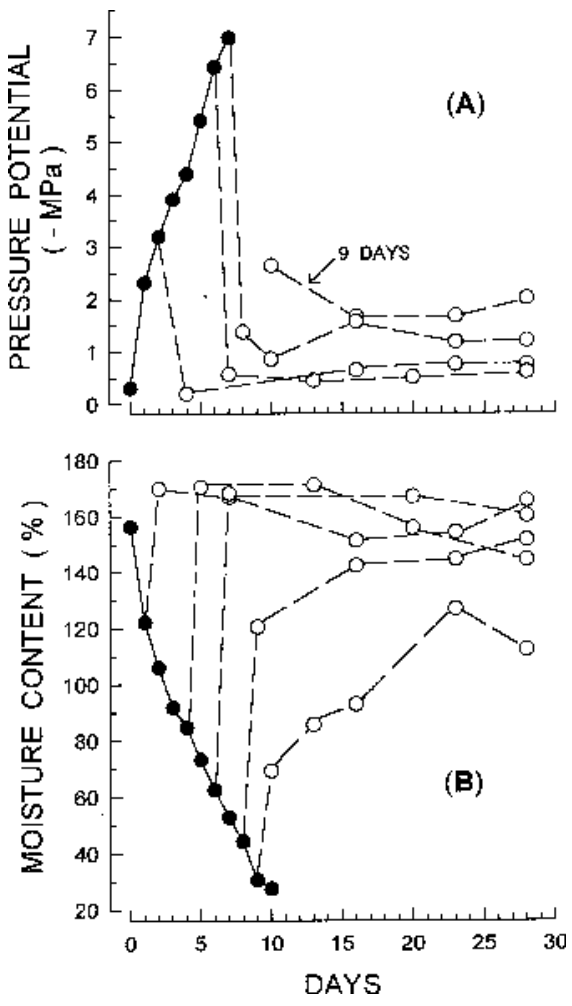

Fig. 4. (A) Xylem pressure potential and (B) moisture content of branches of Leyland cypress after various drying times at $21 \mathrm{C}$ and $50 \% \pm 10 \%$ relative humidity (Expt. 1). (•) Branches out of water; $(\bigcirc)$ branches recut after designated periods of drying, and resupplied with water. Xylem pressure potential could not be determined on branches dried $>7$ days. Means for dry branches usually had SE $<5 \%$ of the mean. Following rehydration, SES were rarely $20 \%$ of the mean, normally $<10 \%$. parently inhibited bacteria and fungi. Red cedar did not last beyond the first month.

The critical MC (CMC) is the MC below which a tree will not rehydrate fully when recut and stood in water (Van Wagner, 1963), and the damage threshold is the MC where tissues experience irreversible damage (Montano and Proebsting, 1986). Reported values for several Christmas tree species are -3.0 to-4.9 MPa (Chastagner, 1986; Hinesley, 1984; Hinesley and Snelling, 1988; Montano and Proebsting 1985, 1986, 1988; Seiler et al., 1988). A tree reaches the damage threshold first. In our experiments, Leyland cypress, Fraser fir, and red cedar withstood drying to -4.0 to $-4.5 \mathrm{MPa}$ with little adverse effect, but additional drying notably reduced the quality (e.g., dryness, discoloration, faded foliage, loss of foliage, and brittleness) of one or more branches in each treatment group, despite significant water uptake. For example, after 8 days of drying (twig MC $\approx 45 \%$ ), branches of all Leyland cypresses in Expt. 1 (Fig. 4B) had developed a tendency for foliage to crumble to some extent when touched or shaken on the 28th day.

Leyland cypress dried more slowly than eastern red cedar but more quickly than Fraser fir. When continuously supplied with water, postharvest life of Leyland cypress was longer than eastern red cedar and at least equal to Fraser fir. Thus, results suggest that Leyland cypress might have some potential in the wholesale Christmas tree market.

\section{Literature Cited}

Chastagner, G.A. 1986. Effect of postharvest moisture stress on the keeping qualities of Douglas-fir Christmas trees. HortScience 21:485-486.

Hinesley, L.E. 1984. Measuring freshness of cut Fraser fir Christmas trees. HortScience 19:860 862.

Hinesley, L.E. and L.K. Snelling. 1988. Water relations of cut eastern red cedar Christmas trees. HortScience 23:589-591.

Montano, J.M. and W.M. Proebsting. 1985. Effects of drying on cut Douglas-fir. J. Amer. Soc. Hort. Sci. 110:751-754.

Montano, J.M. and W.M. Proebsting. 1986. Storage of cut Douglas-fir: Relationship to the damage threshold. HortScience 21:1174-1175.

Montano, J.M. and W.M. Proebsting. 1988. Development of the abscission zone in needles of Douglas-fir. J. Amer. Soc. Hort. Soc. 113:133137.

Schoenike, R.E. and M.T. Gaffney. 1989. Leyland cypress: A tree of beauty. Clemson Univ., Dept. of Forestry, Clemson, S.C.

Seiler, J.R., T.J. Nichols, and D.J. Paganelli. 1988. Rehydration characteristics of cut white pine and Norway spruce Christmas trees. HortScience 23:164-166.

Van Wagner, C.E. 1963. Flammability of Christmas trees. Canada Dept. of Forestry Publ. 1034. Ottawa, Canada. 